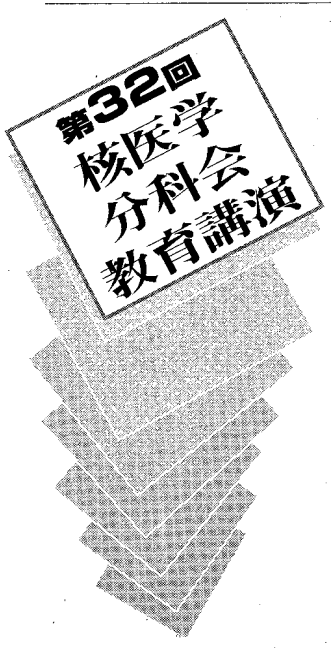

1996年 4 月 1 日

パシフィコ横浜会議センター

盾湯のSPECT診断

戸川貴史

千葉県がんセンタ一核医学診療部

\title{
Tumor Diagnosis Using SPECT
}

TAKASHI TOGAWA

Division of Nuclear Medicine, Chiba Cancer Center

\section{1. 畽韵SPECTの意義}

腫瘍の画像診断には現在多くのmodalityが用いられ ているが，CTやMRIなどの断層画像なしには腫瘍の 治療が不可能であるといっても過言ではない，すなわ ち，手術に際しては切除範用の決定に，また放射線治 療に执いては照射野の設定などにこれらの画像情報が 必要であり，癌病巣がどこに局在するかだけでなく， 周囲臓器や組織へどれくらい搪がっているかを知るた めには，これらの解剖学的画像がなくてはならない. これに対して，腫瘍の核医学診断に打いては，腫瘍に 親和性のある放射性医薬品を用いて腫湯を陽性に描画 し，全身を検索することによって腫瘍の局在や拡がり を容易に知ることが出来る。しかしながら，この全身 シンチグラフィに用いられる核医学診断装置の分解能 はMRIやCTよりも劣って扔り，全身シンチグラフィ だけでは小さな病巣を検出できない場合が多い。これ は，腫瘍核医学がMRIやCTほど普及しない要因の一 つと考えられる。腫場診断の領域でも，核医学がMRI やCTと同程度まで診断精度を上げるためにはやはり 断層画像による評価が不可欠である. SPECT (single photon emission CT) は核医学に扔いて断層画像による 評価を可能にした. SPECTによって病巣を 3 次元的に 把握できるだけでなく，生理的集積と病巣との重なり が除外でき，病巣のコントラストが良好となるため， 通常のシンチグラフィでは検出できないような体内の 深部に存在する病巣まで描出できる。また，SPECTを 撮ることによってはじめて，MRIやCTとほほ同一の 断層面に打いて形態画像と機能画像との対比が容易と なった。さらに最近ではMRIやCTなどの形態学的画 像では知り得ない腫瘍の機能的な画像情報をSPECTに よって提供できることが分かってきた1)。したがっ て, 腫瘍SPECTは癌診断において極めて重要であり, なくてはならない検査手段であるといえる。腫瘍 SPECTなしには腫瘍患者の適切な治療扔よび治療の効 果判定，また経過観察に扮ける再発巣の検出などが正 しく行えないといっても過言ではない. 本稿では具体 的に症例を呈示しながら，どういう場合に腫瘍SPECT を行えば実際の臨床に役立つかを解説する。

\section{2. 睡瘍SPECTに用いられる放射性医楽品}

これまでにも多くの放射性医薬品が開発されてきた が，現在，保険適応があり臨床的にtumor imaging製㓣 として用いられているものはクエン酸ガリウム $(\mathrm{Ga}-$ 67)，塩化夕リウム(T1-201)，拧よびI-131 MIBGのみで ある。I-131 MIBGの集積は褐色細胞腫や甲状腺䯋様癌 などの限られた癌に特異的に見られるのに対して，Ga67やTl-201は多くの癌に非特異的に集積し, 腫瘍 SPECTに抢いても雨核種が最も使いやすい薬郕であ る。ささらに最近，心筋血流製荗として保険適応となっ たTc-99m MIBIの腫瘍集積性が新たに注目されてい る。その他にも，甲状腺䯣様癌に 5 価の Tc- $99 \mathrm{~m}(\mathrm{~V})$ DMSAや，ソマトスタチンレセプターが陽性の腫瘍にIn111 Octoreotide(オクトレオスキャン)が有用であるが, これらの薬剮の腫瘍SPECTに扮ける臨床データの蓄積 はまだGa-67やTl-201ほど多くない。本稿ではGa-67と T1-201およびTc-99m MIBI SPECTについて述べる.

\section{Ga-67 SPECT}

わが国では腫瘍シンチグラフィといえばGa-67の検 查をさすほどGa-67シンチグラフィはpopularな検査と なっている。腫瘍に関連する核医学検査の中では最も 多く行われ，検查数は年間 20 万件であるが，このう ち，Ga-67 SPECTが行われているのはわずかに4000件 のみである2)。したがって，わが国ではGa-67 SPECT がほとんど行われていないと言っても過言ではない。 Ga-67.の有用な疾患は, 悪性リンパ腫, 頭頸部腫瘍, 肺癌であるが，SPECTを用いることによって，さらに より詳細に病変の局在を知ることができる。実際に Ga-67 SPECTが有用であった症例を解説する。

Fig.1a，1bは硬口蓋の悪性リンパ腫のMRI画像(冠状 断)で，硬口蓋に20mm大の腫瘍を 2 ヶ認める. Fig. 1c は頭部のGa-67スポット像である。異常集積はまった く指摘できない。しかし，Ga-67 SPECT(Fig.1d)では 硬口蓋に 2 力所の異常集積を認め( 致した。本例はGa-67が集積しやすい悪性リンバ腫で あるが通常のplanar imageのみでは病巣が検出できな かった。しかし，SPECTをとれば病巣が極めて明瞭に 

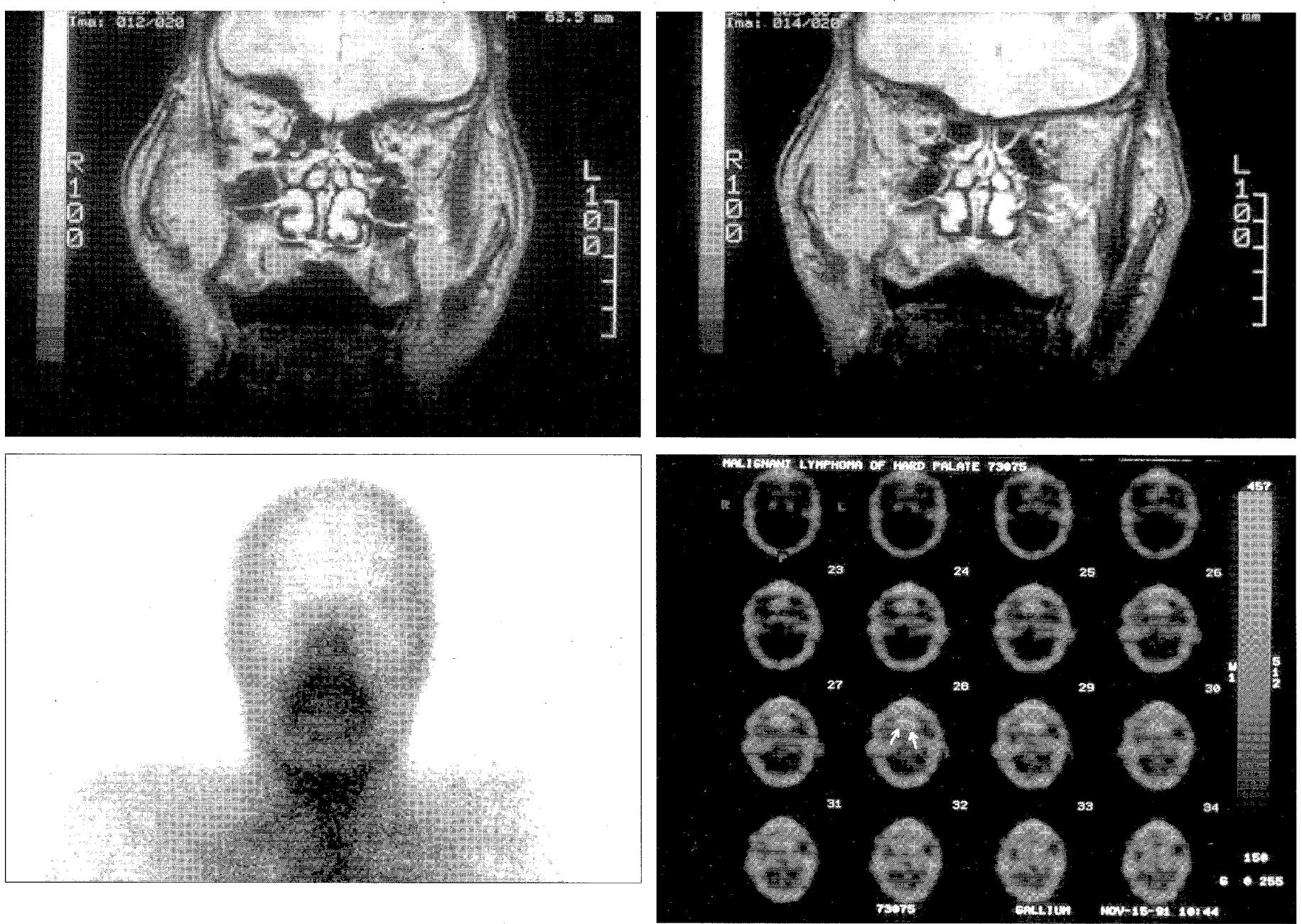

Fig. 1 硬口蓋の悪性リンパ腫

MRI画像(Fig.1a，1b)では，硬口蓋に20mm大の腫瘍を2個認めた．頭部のGa-67スポッ 卜像(Fig.1C)では異常集積像を指摘できなかった.しかし, Ga-67 SPECT(Fig.1d)で は硬口蓋に 2 力所の異常集積を認めた $(\uparrow)$.

描出できることがわかる。このようにGa-67 SPECTの 診断能は通常のplanar imageよりもはるかに優れてい $ろ^{3)}$. 治療後の再発巣の検出にもGa-67 SPECTは有用 である。再発巣の検出にGa-67 SPECTが有用であった 症例を呈示する。

Fig.2a，2b，2cは，喉頭癌と舌癌の重複癌で術後の 再発症例である。舌喉頭全摘，広背筋皮并による再建 術後に，ガリウムシンチグラフィが退院前の検査とし て行われた。スポット像(Fig.2a)では胸骨上縁の気管 口に生理的な集積立進が認められるが，咽頭や譙頭部 には特に異常を指摘できなかった。しかしながら，咽 頭部のSPECTを撮像すると，咽頭後壁にガリウムの異 常集積が認められた(Fig.2b). 同部位のdynamic CTを みても特に異常所見は得られなかった(Fig.2c). しか し，局所の擦過細胞診により扁平上皮癌が確認され， 局所再発であることが明らかとなった。したがって， 本症例ではGa-67 SPECTが腫瘍の再発を最も早く検出 した事になる。

Fig.3は肺癌術後患者の胸部CTとGa-67 SPECT像拧 よび胸部CTとGa-67 SPECT像の加算画像を示す。術 後の経過観察中に血清CEA值が高值を示し再発が疑わ れたが，胸部X線写真では無所見であった。胸部CTで
は右肺動脈に重なってリンパ節腫大を疑わせるが，明 らかな異常を指摘できない.しかし，Ga-67 SPECTで は右肺門部に明らかな異常集積を認め, \#11が\#12リン パ節の腫大を強く疑う所見であった。しかし，この時 点では再発の確診が得られず，3 カ月後の胸部X線写 真で右上葉が無気肺となり，気管支鏡下の擦過細胞診 で扁平上皮癌が証明された。したがって，この症例で もGa-67 SPECTがもっとも早く異常を指摘し再発の検 出に極めて有用であった。

\section{TI-201 SPECT}

T1-201の腫瘍集積性が初めて報告されたのは1976年 であり，その後，相次いで各種の腫瘍におけるT1-201 の有用性が確認された。しかしながら，その当時は Ga-67が全盛の時代であり，Tl-201もGa-67に比べ腫瘍 をどの程度陽性に描画できるかという観点からの検討 がなされ，その結果T1-201の腫瘍検出率はGa-67と同 等またはGa-67よりも劣るというように認識されてい た.しかし，T1-201の腫瘍イメージング製剤としての 有用性が再評価され4), 多くの臨床応用がなされ，か ってのGa-67と立場が逆転しようとしている。これに は，T1-201による腫瘍診断にSPECTが応用され良好な 
結果が得られたこと5), さらには 3 検出器回転型をは じめとするSPECT装置の改良によりSPECT装置の分 解能や画質が向上したことがおおいに寄与している。

T1-201はイオン半径がKと類似した一価の陽イオン であり，体内ではKと同様にNa-K-ATPase活性を反映 し集積する. 小腸などの腺組織はKに富みT1-201も腺 組織への集積が高い．腺癌ではGa-67が集積しないも のが多いが6)，高分化型腺癌では正常の腺構造が保た れているのでT1-201は良く集積する。組織学的にはほ とんどか腺癌である膵臓癌にも T1-201が集積すること が予測された。しかし，T1-201は特性X線のエネルギ 一が低いため, 通常のシンチグラフィでは体内でphotonが減弱し吸収され深部の病巣を見落としてしま う。また, planar imageのみでは小腸の生理的集積に 重なってしまい, 膵蔵の病巣を判定できない. そこ で, SPECTを行なったところ, 膵蔵癌を陽性描画する ことができだ).

また，Tl-201とGa-67の集積を比較することによっ
て，腫瘍の組織型や分化度をある程度推定することが できる。Ga-67は増殖の盛んな細胞，未分化な細胞に より多く集積する。また，Ga-67は癌細胞のトランス フェリンレセプタ $(\mathrm{TfR}) に$ 結合し腫瘍細胞内に取り込 まれていくが，すべての腫瘍に集積するわけではな く, 肺癌では腺癌など細胞表面にTfRがない組織型で は集積しない(8).これに対して，T1-201は腺癌に集積 する6).したがって, 肺癌において病巣のT1-201とGa67の摂取を比較すると，聏平上皮癌や小細胞癌では病 巣に打けるGa-67の摂取がT1-201よりも多いが，腺癌 では分化度によ々て両核種の掑取が異なっている9). すなわち，低分化腺癌では扁平上皮癌や小細胞癌と同 じようにGa-67の摂取がT1-201よりも多いが，高分化 腺癌においてはGa-67の瞟取がほとんどなくT1-201の 集積が強い.

腫瘍のSPECT診断では，CTやMRIでは知り得ない 機能的な情報を画像化することができる。手術後の解 剖学的な構造は正常とは異なるため, CTでは術後の
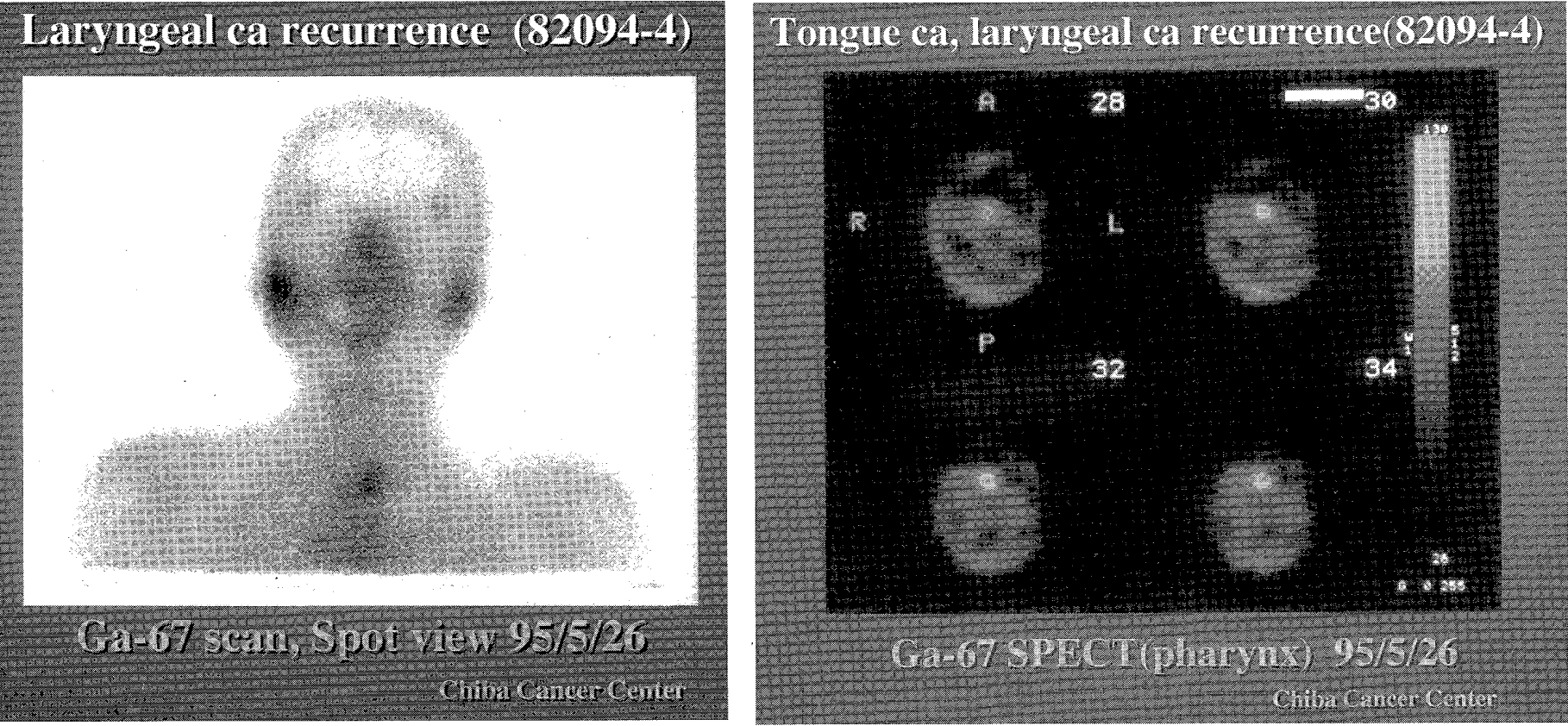

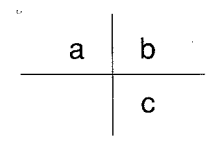

Fig. 2 喉頭癌と舌癌の重複癌症例 スポット像(Fig.2a)では胸骨上縁の気 管口に生理的な集積え進が認められた が、咽頭や喉頭部には特に異常集積を 認めなかった．しかし，咽頭部の SPECTを撮像すると、咽頭後壁にガ リウムの異常集積が認められた (Fig.2b). 同部位のdynamic CTをみ ても特に異常所見は得られなかった (Fig.2c).

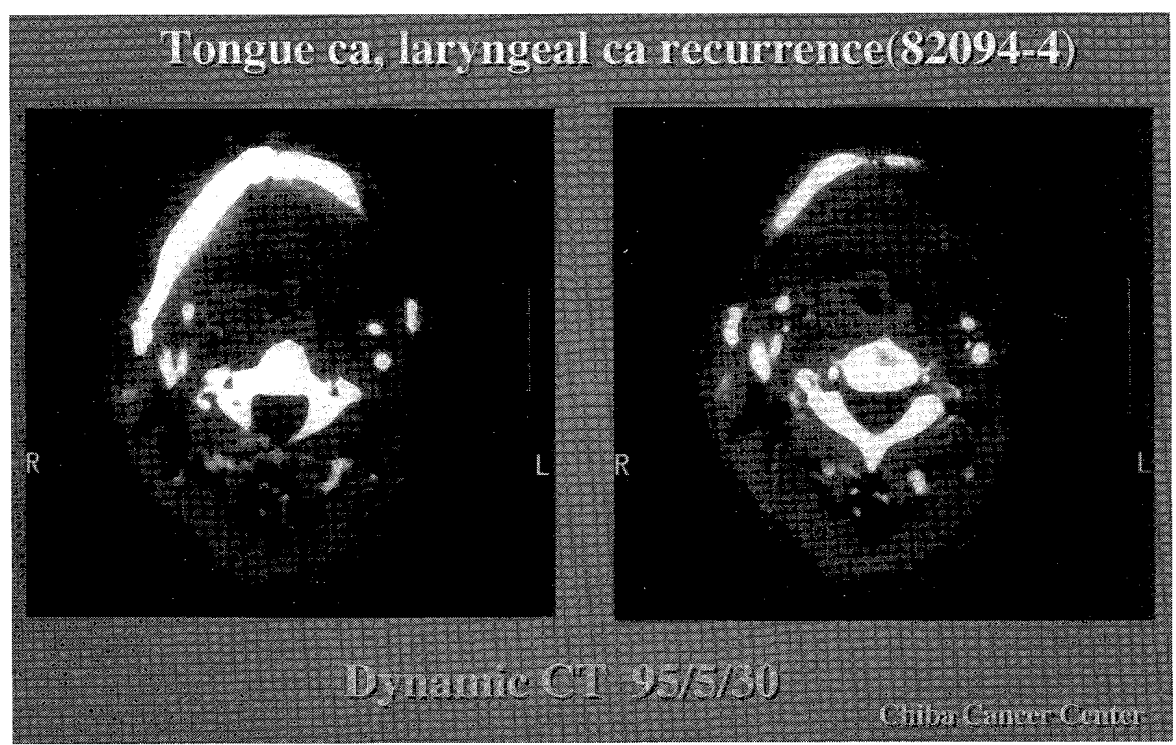




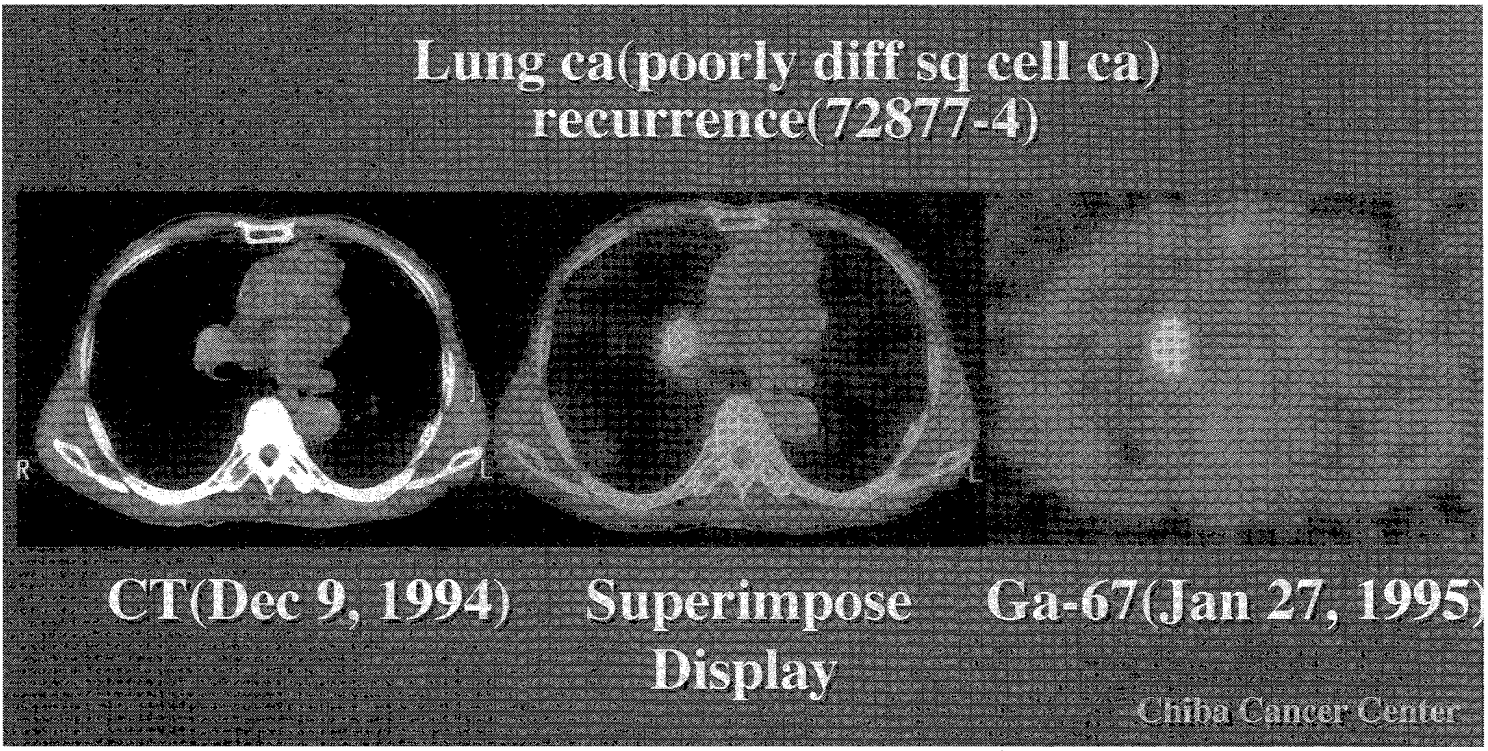

Fig. 3 肺癌術後患者の再発 胸部CTとGa-67 SPECT像および胸部CTとGa-67 SPECT像の加算画像を示す．胸部CTでは右肺 動脈に重なってリンパ節腫大を疑わせるが，明らかな異常を指摘できない.しかし，Ga-67 SPECT では右肺門部に明らかな異常集積を認め，\#11か\#12リンパ節の腫大が強く疑われた。

(Fig.4a) と $\mathrm{Tl}-$ 201 SPECT像 (Fig.4b)であ る.MRIでは 右眼球後方に high intensity lesionを認め腫 瘍再発が疑わ れたが，T1-201

SPECTでは全 く異常集積が 認められず再 発は否定さ れ，放射線障 害と診断され た。通常，再発 加否かの確定 診断には針生 検か細胞診が 行われるが，

肉芽か再発かの鑑別は難しい．放射線治療後の再発 と壊死巣の鑑別や，化学療法や放射線治療後の效果判 定も形態画像だけでは充分評洒できず，腫瘍SPECTに よってはじめて判定可能となる場合も多い. 治療後も 残存する腫瘤の活性度の評価，放射線治療後の再発と 壊死との鑑別，治療効果の判定などの腫瘍の機能的評 価には現在ではGa-67よりもむしろTl-201が用いられ ている.その理由としてはTl-201の方が腫湯のVIABLE/NECROSIS集積比が高い事10)，炎症巣への集積 がGa-67よりも少ない事，などが考えられる。再発巣 の検出にもT1-201 SPECTは極めて有用である。

Fig.4a，4bは上咽頭癌の放射線治療 3 年後に右目の 視力障害を訴えてきた患者のMRI (fat supression) 像

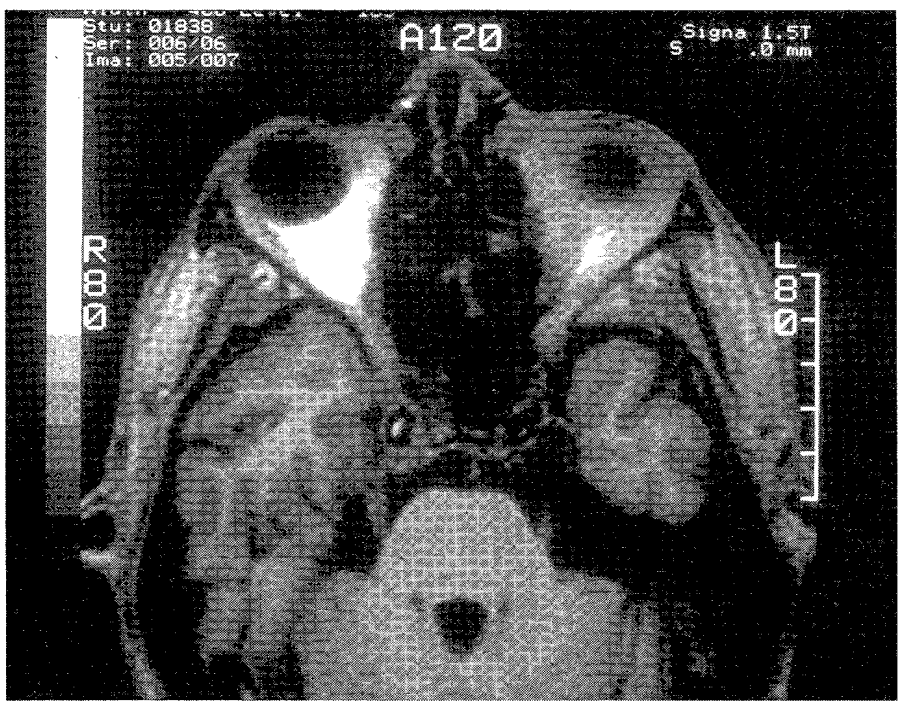

(a)
本例ではこれらの細胞診が部位的に不可能であり， T1-201 SPECTが確定診断に極めて役立った。もし， T1-201 SPECTがなければMRIからは腫瘍再発が疑わ れ追加照射が行われ，さらに重篤な放射線障害が引き 起こされた可能性がある。

Fig.5は舌癌のイリジウム針舌組織内刺入後の再発 例であるが，治療 6 力月㖟に右舌根部に潰瘍形成が認 められ，擦過細胞診で癌再発が証明された。 dynamic CTでは癌の再発がどこまであるか範囲の特定が困難 であるが，T1-201 SPECTでは再発が舌の正中にまで 及んでいるのがわかり，実際の腫湯再発巣の分布と良 く一致していた。このようにT1-201 SPECTは再発巣 の検出にも極めて優れている。その後，上咽頭癌にお

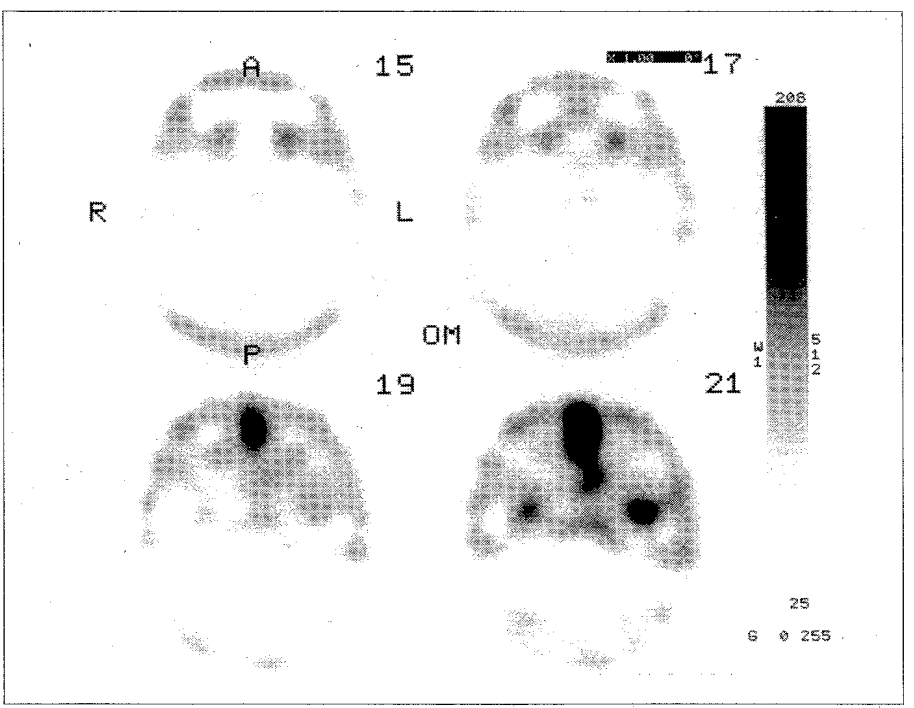

(b)

Fig. 4 上咽頭癌の放射線治療後

MRI (fat supression)像(Fig.4a)では右眼球後方にhigh intensity lesionを認め腫瘍再発が疑われたが，TI-201 SPECT像 (Fig.4b)では全く異常集積が認められず再発は否定され，放射線障害と診断された。 
いてはとくに放射線治療後の效果判定や経 過観察にもT1-201 SPECTが有用であること がわかった。

上咽頭癌は放射線治療と化学療法で治療 されるが，その効果判定には通常X線CTか MRIが用いられている。治療終了時のMRI を治療前と比較すると，腫瘤が完全に消失 するComplete Response (CR)の場合には， 問題ないか腫瘤が残存するPartial Response （PR）の場合に，腫瘍がどの程度viableであ るのか判定しなければならない。治療直後 のMRI画像がPRの場合でもT1-201 SPECTで 病巣への集積が完全に消失している場合に は，経過を追っていくと腫瘤が次第に消失 することが分かっだ11)。すなわち，Tl-201 SPECTによって形態学的画像に先行して放 射線の治療効果を評価できる。

\section{Tc-99m MIBI SPECT}

Tc-99m MIBIはT1-201と同様一価の陽イオンであ り，体内分布も腫瘍への集積もT1-201に類似してい る。しかし, Tc-99m MIBIの集積は細胞表面のP糖夕 ンパク $(\mathrm{PgP})$ が関与しており，PgP陽性のものではTc99m MIBIの集積がなく，PgP陰性のものではTc-99m MIBIの集積があると考えられている．PgPは抗癌剤を 細胞の外へ汲み出してしまうポンプの役割をはたし， $\mathrm{PgP}$ が陽性であると抗癌剤が耐性になってしまう。し たがって，Tc-99m MIBIの集積の有無から癌細胞が抗

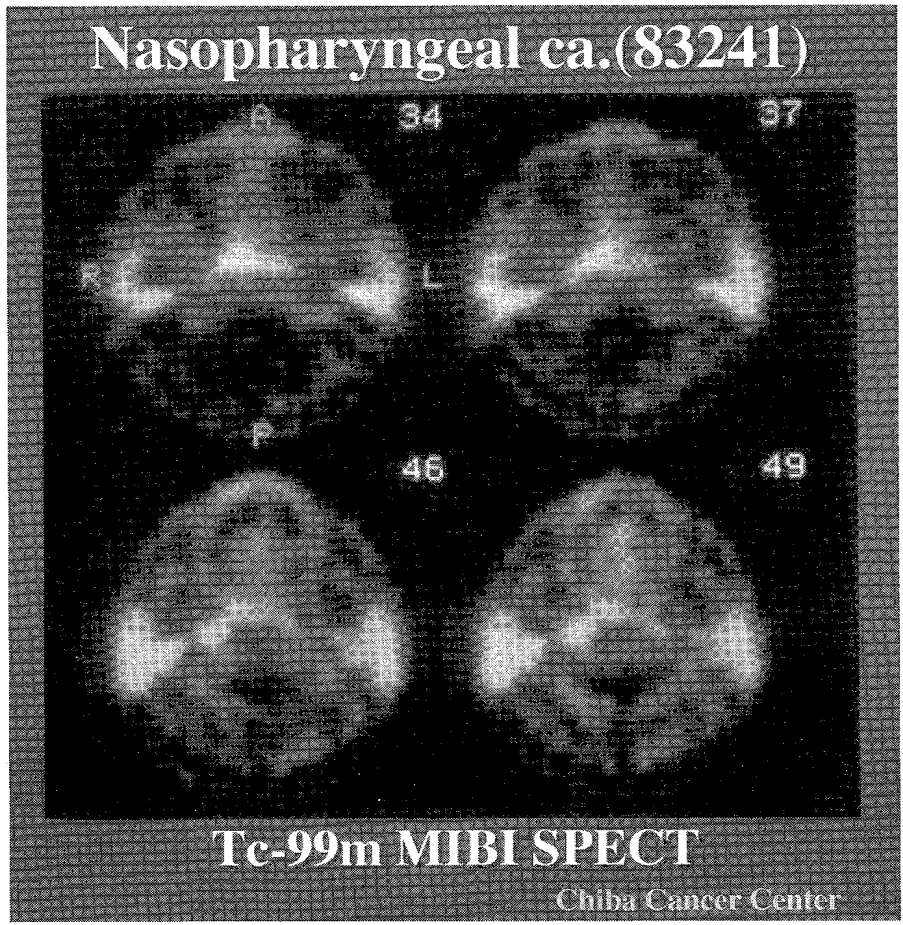

Fig.6
Tongure cancer focal recut rence $82004=4$

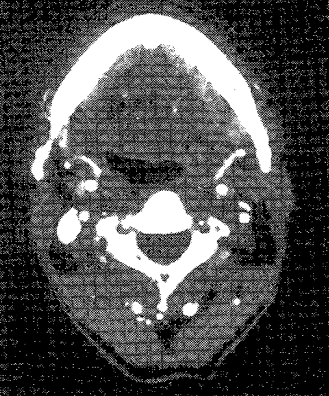

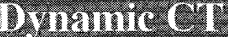

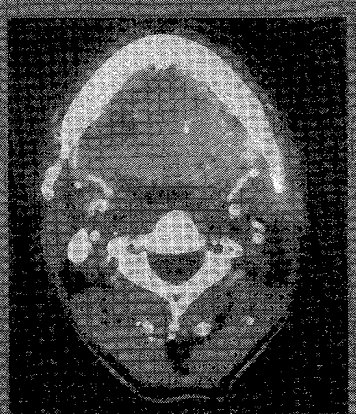

Siprevimiose CISplat

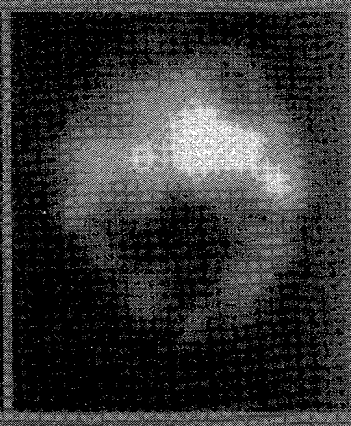

DE2IMTLES
Fig. 5 舌癌再発例

dynamic CTでは癌の再発がどこまであるか範囲の特定が困難である が、TI-201 SPECTでは再発が舌の正中にまで及んでいるのがわか り，実際の腫瘍再発巣の分布と良く一致していた。
癌剤に多剂耐性になっているかどうかを画像化できる 可能性がある。また，臨床データの蓄積はないが， Tl-201集積 (+)Tc-99m MIBI集積(-)である腫瘍，また は, delayed imageでTc-99m MIBIの集積がwashout れてしまう腫瘍では，多剤耐性癌であることが予想さ れるが12，今後の検討が待たれる。腫瘍をどの程度陽 性に描出できるかに関して，我々も上犑頭癌に抢いて Tc-99m MIBI SPECTを検討したが，T1-201 SPECTと ほぼ同様な結果であった13)。Fig.6，Fig.7はそれぞれ

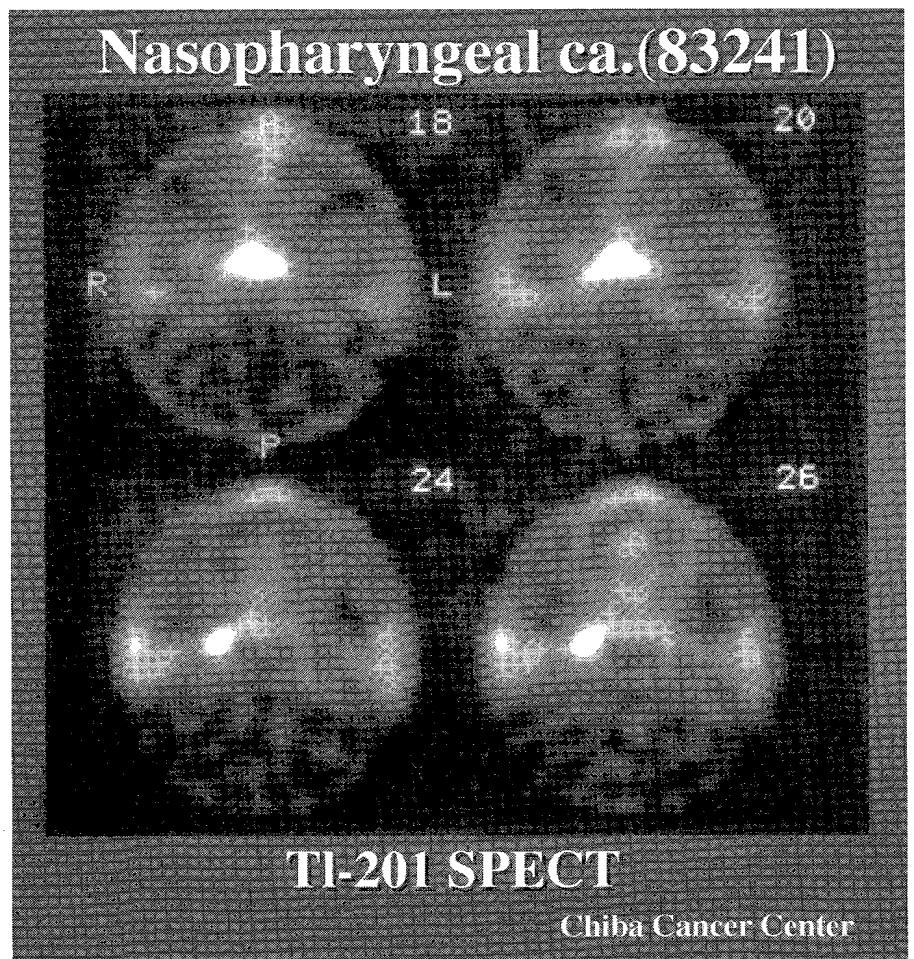

Fig.7

Fig. 6, 7 上咽頭癌

Tc-99m MIBI SPECT (Fig.6) とTI-201 SPECT (Fig.7)である.いずれも，上咽頭腫瘍と右後咽頭腔リンパ節転移巣が明 瞭に描出されている. 病巣への集積の範囲や程度は極めて類似している。 


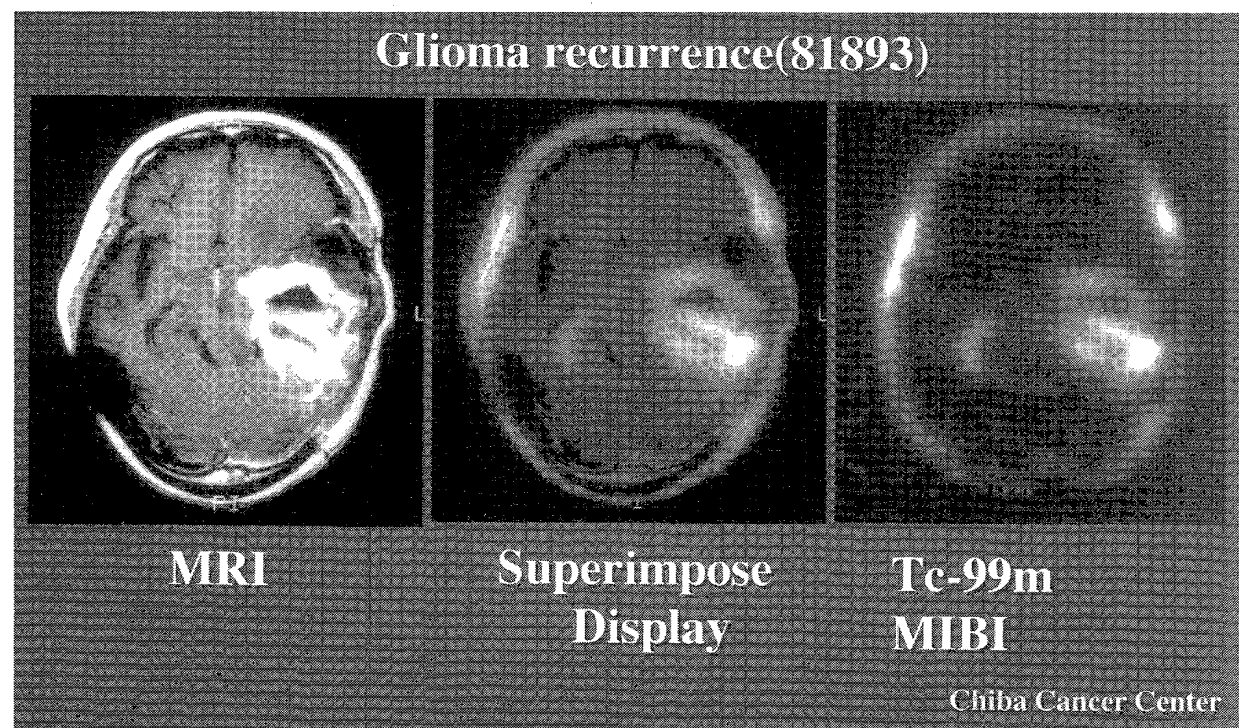

Fig. 8 脳腫瘍再発例

MRI画像とTc-99m MIBI SPECTおよび両者の加算画像である.MRIでは造影剂 が均一にenhanceされているのに対して，Tc-99m MIBI SPECTではTc-99m MIBI の集積が不均一であり, 病巣の不均一性または腫瘍の多様性がTc-99m MIBI SPECTによってのみ画像化されていた.

同一症例における上咽頭癌のTc-99m MIBI SPECTと T1-201 SPECTであるが，病巣への集積の範囲や程度 は極めて類似している。しかし，Tc-99m MIBIの方が 投与量が多く画像は鮮明である。Fig.8は脳腫瘍再発 例におけるMRI画像とTc-99m MIBI SPECTおよび両 者の加算画像であるが, MRIでは造影剤が均一にen- hanceされているのに対して， Tc-99m MIBI SPECTではTc99m MIBIの集積が不均一であ り，病巣の不均一性または腫瘍 の多様性がTc-99m MIBI SPECT によってのみ画像化されてい 万.

\section{6. まとめ}

腫瘍診断に扔ける核医学診断 は腫瘍の機能を評価する上で極 めて重要な情報を提供する。ま た，SPECTを行うことによっ て, 通常のplanar imageでは検出 できない病巣が描出される。形 態学的断層像であるMRIやCTと の対比をするためにも，機能画 像であるSPECTは必要であり， 時にはMRIやCTでは知り得ない 機能的情報が腫痐SPECTによっ てはじめて画像化される。したがって, 腫瘍SPECTは 腫瘍患者の適切な治療, 治療効果の判定抢よび経過観 察などの総合的な腫陽診断には不可欠な検査手段であ り,さらに多くの施設で腫瘍SPECTが心筋や脳 SPECTと同レベルまで普及することが望まれる.

参考文献

1) 戸川貴史, 油井信春 : 骨・腫瘍の核医学-他のモダリティ との比較を含めて. 新医療, 3, 80-84, (1996).

2) 第 3 回全国核医学診療実態調査報告 II Radioisotope: 42, 10, 53-70, (1993).

3) Font D, Israel O, et al.: Ga-67 SPECT before and after treatment of lymphoma. Radiology, 175, 515-519, (1990).

4) 戸川貴史: 腫瘍イメージング製剤としてのTl-201の現状.Isotope News, 12, 14-15, (1992).

5) 戸川貴史 : 3 検出器を用いたSPECTの臨床. 放射線医学物 理, 14 (2), 51-57, (1994).

6) Togawa T, Suzuki A, et al.: Relation between Tl-201 to Ga67 uptake ratio and histological type in primary lung cancer. Eur. J Cancer \& Clin. Oncol., 21, 925-930, (1985).

7) 戸川貴史, 油井信春, 他：Tl-201 SPECTによる橧癌診断. 核医学, 28, 1475-1481, (1991).

8) Tsuchiya Y, Nakao A et al.: Relationship between gallium-
67 citrate scanning and transferrin receptor expression in lung disease. Chest, 102, 530-534, (1992).

9) Togawa T, Satoh T, et al.: T1-201 to Ga-67 uptake ratio as an indicator for predicting tumour doubling time in human pulmonary neoplasms, Br. J. Cancer, 53, 557-560, (1986).

10) Ito $Y$, Muranaka A, et al.: Experimental study on tumor affinity of Tl-201 chloride. Eur. J Nucl. Med., 3, 81-86, (1978).

11) 戸川貴史，油井信春，他：T1-201 SPECTによる上咽頭腫瘍 の治療効果判定. 頭頸部腫瘍, 22(1), 36-42, (1996).

12) Kostakoglu L, Caner B, et al.; Clinical validation of the influence of MDR expression on Tc-99m-Sesta MIBI uptake. Eur. J. Nucl. Med., 22 (8), 734, (1995).

13) 松野典代, 油井信春, 戸川貴史, 他：Tc-99m MIBI SPECT による頭頸部腫瘍の評価。映像情報，27，1211-1215， (1995). 